\title{
GAMBARAN KEPATUHAN MINUM OBAT PADA PENDERITA TUBERKULOSIS PARU
}

\author{
Description of Medication Adherence in Pulmonary Tuberculosis Patients
}

\author{
Ni Luh Kadek Fitria Dewi ${ }^{1}$, Ni Luh Putu Dewi Puspawati ${ }^{2}$, I Made Sumberartawan ${ }^{3}$ \\ ${ }^{I}$ Program Studi S1 Keperawatan, STIKES Wira Medika Bali, Denpasar, Bali, Indonesia \\ ${ }^{2}$ Departemen Keperawatan Medikal Bedah, STIKES Wira Medika Bali, Denpasar, Bali, Indonesia \\ ${ }^{3}$ Rumah Sakit Umum Daerah Sanjiwani Gianyar, Gianyar, Bali, Indonesia \\ Korespondensi : puspawati.dp@gmail.com
}

\begin{abstract}
ABSTRAK
Tuberkulosis merupakan penyakit infeksi menular yang upaya pengendaliannya menjadi salah satu target dunia yaitu Sustainable Development Goals (SDGs). Kepatuhan minum obat pada pasien TB paru merupakan kendala yang sering dihadapi oleh pasien. Tujuan dari penelitian ini adalah untuk mengetahui gambaran kepatuhan minum obat pada penderita Tuberkulosis Paru di wilayah kerja Puskesmas I dan III Denpasar Utara. Rancangan penelitian ini adalah penelitian deskriptif. Jumlah sampel sebesar 42 orang dengan teknik sampling purposive sampling. Hasil penelitian ini menunjukan sebagian besar responden memiliki kepatuhan tinggi yaitu sebanyak 29 orang $(69 \%)$. Jumlah penderita yang memiliki PMO di rumah yaitu sebanyak 28 orang $(66,7 \%)$. Tingginya kepatuhan minum obat pada penelitian ini karena adanya keinginan untuk sembuh dari diri sendiri dan dukungan keluarga serta informasi yang lengkap dari petugas kesehatan. Hal ini juga dikarenakan puskesmas memiliki program khusus untuk menanggulangi TB yaitu P2TB yang melakukan kunjungan rumah setiap seminggu dua kali. Ada beberapa responden dengan kepatuhan yang rendah disebabkan karena rendahnya motivasi yang dimiliki oleh responden. Saran kepada pihak puskesmas diharapkan program Puskesmas terkait TB yaitu P2TB ditingkatkan.
\end{abstract}

Kata Kunci : tuberkulosis paru, kepatuhan minum obat, pengawas menelan obat

\section{ABSTRACT}

Tuberculosis is a infectious disease which becomes one of the target in Sustainable Development Goals (SDGs). Medication adherence in patients with pulmonary tuberculosis is a problem often faced by patients. The purpose of this study was to describe medication adherence in patients with Pulmonary Tuberculosis in the working area of PHC I and III North Denpasar. Method: The design of this study is descriptive research. Sample size was 42 people recruited by purposive sampling technique. Result: The results of this study indicate most respondents have high adherence of 29 people (69\%). The number of patients who have Drug Swallowing Supervisor at home is 28 people (66.7\%). Discussion: The high medication adherence in this study was because of their own motivation, family support and complete information from health workers. This was also because the PHC has a special programs to cope with Tuberculosis called P2TB which visits the house twice a week. On the other hand there are also respondents with low adherence because the patients have low motivation. It is suggested to improve and maintain P2TB.

Keywords: pulmonary tuberculosis, medication adherence, drug swallowing supervisor 
Ni Luh Kadek Fitria Dewi: Gambaran Kepatuhan Minum Obat pada Penderita Tuberkulosis

Paru

\section{PENDAHULUAN}

Tuberkulosis merupakan salah satu penyakit menular yang masih menjadi permasalahan kesehatan di dunia sampai saat ini. Tuberkulosis juga merupakan penyakit infeksi menular yang upaya pengendaliannya menjadi salah satu target dunia yaitu Sustainable Development Goals (SDGs). SDGs menetapkan TB sebagai bagian dari tujuan di bidang kesehatan yaitu mengakhiri epidemic AIDS, Tuberkulosis (Kementrian PPN/Bappenas, 2017).

Data World Health Organization (WHO) tahun 2014 menunjukkan jumlah penderita TB Paru pada tahun 2013 di benua Asia terdapat 56\%, Afrika 29\%, Regional Mediterania Timur 8\%, Eropa 4\%, dan yang paling kecil beban penderita TB adalah wilayah Amerika 3\% dari total jumlah penderita TB paru di dunia (WHO, 2014). Tuberculosis Paru diperkirakan masih menyerang 9,6 juta orang dan menyebabkan 1,2 juta kematian pada tahun 2014. Data WHO di kawasan' Asia Tenggara menunjukkan bahwa kematian akibat TB Paru sekitar 2.000 jiwa setiap hari (WHO, Global Tuberculosis Report, 2015). Kasus TB Paru di Indonesia pada tahun 2015 adalah sebanyak 330.910 kasus. Angka ini meningkat bila dibandingkan semua kasus TB Paru yang ditemukan pada tahun 2014 yaitu sebesar 324.539 kasus. Laporan menurut Diskes menunjukkan Case Notification Rate (CNR) Provinsi Bali tahun 2014 secara umum mengalami peningkatan, dari tahun 2012 CNR Provinsi Bali sebesar 71 per 100.000 penduduk dan pada tahun 2014 meningkat menjadi 74 per 100.000 penduduk. Daerah yang memiliki jumlah penderita TB Paru terbanyak adalah kota Denpasar yaitu sebesar 50,76\% per 100.000 penduduk di tahun 2015 (Dinkes Prov. Bali, 2015).

TB Paru adalah penyakit yang dapat diobati dan disembuhkan dengan pengobatan selama 6 bulan sampai 1 tahun (Info DATIN Kementerian Kesehatan RI, 2016). Apabila penderita menghentikan pengobatan maka kuman TB Paru akan mulai berkembang biak lagi. Hal ini berarti penderita mengulangi pengobatan intensif selama 2 bulan pertama (WHO, 2013). Pengobatan yang tidak teratur dan kombinasi obat yang tidak lengkap, dapat menimbulkan kekebalan ganda kuman TB terhadap Obat Anti Tuberkulosis (OAT) atau Multi Drug Resistance (MDR). WHO (2013) memperkirakan di Indonesia terdapat 6.800 kasus baru TB dengan Multi Drug Resistance (TB MDR) setiap tahun.

Menurut Tabrani (2010), strategi DOTS (Directly Observed Treatment Short Course) merupakan prioritas utama dari World Health Organization (WHO) dalam mengontrol angka kejadian TB Paru. Untuk mendukung strategi DOTS, dibutuhkan kedisiplinan dari penderita TB itu sendiri dalam pengobatannya. Selain itu untuk meningkatkan kepatuhan minum obat pasien TB Paru dibutuhkan pengawasan langsung oleh Pengawas Menelan Obat (PMO) (Netty, 2013). Dari hasil penelitian Pameswari , Halim, \& Yustika (2016) tingkat kepatuhan minum obat pada penderita Tuberkulosis Paru belum mencapai $100 \%$.

Data Dinas Kesehatan Kota Denpasar menyebutkan bahwa pada tahun 2015 jumlah suspek yang berhasil diperiksa dahaknya sebanyak 5304 dan ditemukan BTA+ baru sebanyak $447 \quad(8,5 \%)$. Sedangkan kasus kambuh/gagal adalah sebanyak $37(0,7 \%)$, BTA negatif Ro" positif + TB Extra Paru sebanyak 178 $(3,4 \%)$. Data seluruh puskesmas di kota Denpasar terdapat 28 suspek TB MDR tahun 2015. Terjadinya TB MDR ini disebabkan oleh pasien yang tidak teratur minum obat. Dari hasil studi pendahuluan yang dilakukan di Puskesmas I dan III Denpasar Utara, pada catatan buku register di Puskesmas I Denpasar Utara tahun 2016-2017 didapatkan jumlah penderita TB sebanyak 25 orang. Sedangkan pada catatan buku register di Puskesmas III Denpasar Utara dari bulan Januari tahun 2016 sampai bulan Februari 2017 sebanyak 21 orang.

Berdasarkan uraian di atas maka perlu dilakukan penelitian mengenai "Gambaran Kepatuhan Minum Obat Pada Penderita Tuberkulosis Paru di wilayah kerja Puskesmas I dan III Denpasar Utara“.

\section{TUJUAN PENELITIAN}

Penelitian ini bertujuan untuk mengetahui gambaran kepatuhan minum 
Ni Luh Kadek Fitria Dewi: Gambaran Kepatuhan Minum Obat pada Penderita Tuberkulosis Paru

obat pada penderita tuberkulosis paru serta peran PMO.

\section{METODE PENELITIAN}

Desain

Penelitian ini merupakan jenis Penelitian Deskriptif. Rancangan penelitian yang digunakan dalam penelitian ini adalah penelitian non-eksperimental yaitu rancangan penelitian deskriptif. Rancangan ini mendeskripsikan seperangkat peristiwa atau kondisi populasi saat itu (Hidayat, 2014).

\section{Populasi dan Sampel}

Populasi pada penelitian ini adalah seluruh penderita tuberculosis paru di wilayah kerja Puskesmas I dan III Denpasar Utara. Teknik pengambilan sampel yang digunakan dalam penelitian ini adalah Nonprobability Sampling dengan purposive sampling. Sampel yang digunakan yaitu sebanyak 42 orang dengan kriteria inklusi pasien tuberkulosis paru dalam proses pengobatan tahap lanjutan serta bisa membaca dan menulis. Kriteria eksklusi dalam penelitian ini adalah Pasien Tuberkulosis Paru yang memiliki penyakit penyerta seperti TB-HIV, obstruksi jalan nafas, kerusakan parenkim berat.

\section{Tempat dan Waktu Penelitian}

Penelitian dilaksanakan di wilayah kerja Puskesmas I dan III Denpasar Utara. Pengambilan data dilakukan selama 1 bulan.

\section{Instrumen dan Prosedur Pengukuran}

Instrumen yang digunakan dalam penelitian ini adalah Instrumen atau alat ukur penelitian yang digunakan dalam penelitian ini adalah Morisky Medication Adherence Scale (MMAS). Kuesioner ini dapat mengukur ketidakpatuhan yang disengaja maupun yang tidak disengaja antara lain lupa, kecerobohan, menghentikan pengobatan karena merasa kondisi memburuk. MMAS memiliki reliabilitas dan validitas yang tinggi. Nilai kepatuhan mengkonsumsi obat terdiri 8 skala untuk mengukur kepatuhan penggunaan obat dengan rentang nilai 0 sampai 8. MMAS dikategorikan menjadi 3 tingkat kepatuhan obat : kepatuhan tinggi (nilai 8), kepatuhan sedang (6-7) dan kepatuhan rendah (nilai < 6) (Morisky et al., 2008).

Pemilihan sampel dilaksanakan melalui kunjungan rumah dengan mengunjungi penderita TB Paru satu per satu. Selanjutnya dilakukan pendekatan secara informal dengan calon responden dengan menjelaskan maksud dan tujuan penelitian kepada calon responden yang diteliti. Jika calon responden menolak untuk dijadikan subjek penelitian, peneliti tidak memaksa dan mengormati hak calon responden. Tetapi jika bersedia calon responden menandatangani informed consent (persetujuan) sebagai subjek penelitian. Subjek penelitian mengisi lembar karakteristik repsonden dan lembar kuisioner MMAS yang terdiri dari 8 pertanyaan tertutup (ya/tidak).

\section{Analisa Data}

Data yang dikumpulkan pada penelitian ini berupa data primer karena pengumpulan data dilakukan secara langsung terhadap responden dengan menggunakan alat pengukuran atau alat pengambilan data langsung pada subjek sebagai sumber informasi yang dicari (Nursalam, 2013). Analisa univariat dilakukan pada data karakteristik responden dan kepatuhan pasien.

\section{HASIL PENELITIAN}

Adapun gambaran distribusi responden sebagai berikut :

Tabel 1

Karakteristik Responden $(\mathrm{n}=42)$

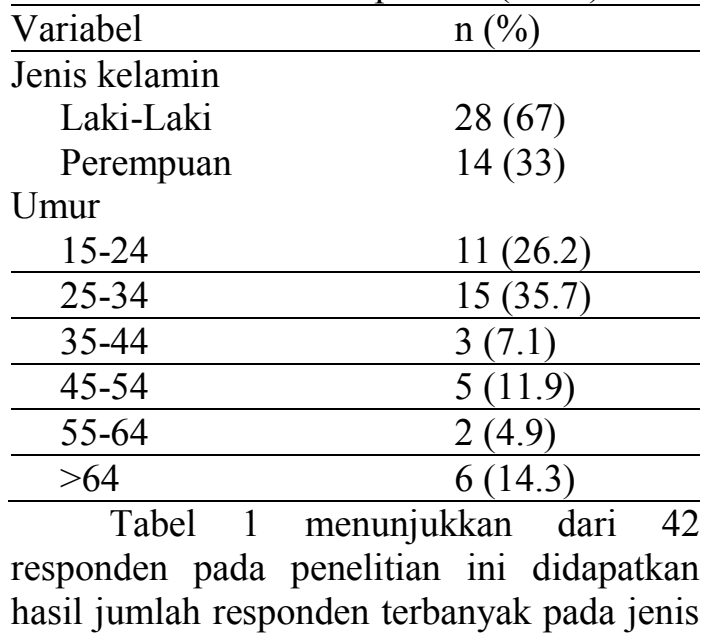


Ni Luh Kadek Fitria Dewi: Gambaran Kepatuhan Minum Obat pada Penderita Tuberkulosis

Paru

kelamin laki-laki yaitu sebanyak 28 orang $(66,7 \%)$. PADA penelitian ini didapatkan hasil jumlah terbanyak pada usia 25-34 tahun sebanyak 15 orang $(35.7 \%)$

Tabel 2

Gambaran Kepatuhan Minum Obat Pada Penderita Tuberkulosis Paru ( $\mathrm{n}=42)$

\begin{tabular}{cc}
\hline Tingkat Kepatuhan & $\mathrm{n}(\%)$ \\
\hline Tinggi & $29(69)$ \\
Sedang & $9(21.4)$ \\
Rendah & $4(9.6)$ \\
\hline Total & $42(100)$ \\
\hline
\end{tabular}

Table 2 menjelaskan hasil pengukuran kepatuhan diperoleh hasil sebagian besar responden memiliki kepatuhan tinggi yaitu 29 orang $(69 \%)$

Tabel 3

Distribusi Keberadaan dan Peran PMO Penderita TB Paru Berdasarkan Wawancara

\begin{tabular}{|c|c|c|c|}
\hline No & Pertanyaan & Jawaban & $\mathrm{n}(\%)$ \\
\hline \multirow[t]{2}{*}{1.} & Apakah bapak/ibu & $\mathrm{Ya}$ & $28(66,7)^{*}$ \\
\hline & $\begin{array}{l}\text { memiliki PMO } \\
\text { dirumah? }\end{array}$ & Tidak & $14(33,3)$ \\
\hline \multirow[t]{2}{*}{2} & Apakah PMO & Ya & $2(7,1)^{* *}$ \\
\hline & $\begin{array}{l}\text { mengetahui semua } \\
\text { jenis obat yang } \\
\text { bapak/ibu minum } \\
\text { setiap hari? }\end{array}$ & Tidak & $26(92,9)$ \\
\hline \multirow[t]{2}{*}{3} & Apakah PMO & $\mathrm{Ya}$ & $28(100)^{* *}$ \\
\hline & $\begin{array}{l}\text { selalu } \\
\text { mengingatkan } \\
\text { bapak/ibu } \\
\text { untuk minum } \\
\text { obat? }\end{array}$ & Tidak & $0(0)$ \\
\hline \multirow[t]{2}{*}{4} & Apakah PMO juga & $\mathrm{Ya}$ & $21(75)^{* *}$ \\
\hline & $\begin{array}{l}\text { mengingatkan } \\
\text { bapak/ibu } \\
\text { untuk } \\
\text { memeriksakan } \\
\text { dahak }\end{array}$ & Tidak & $7(25)$ \\
\hline \multirow[t]{4}{*}{5} & $\begin{array}{l}\text { Apakah PMO rutin } \\
\text { untuk mengajak }\end{array}$ & Ya & $\begin{array}{c}23 \\
(82,1)^{* *}\end{array}$ \\
\hline & bapak/ibu & Tidak & $5(17,9)$ \\
\hline & $\begin{array}{l}\text { ke pelayanan } \\
\text { kesehatan seperti }\end{array}$ & & \\
\hline & Puskesmas? & & \\
\hline \multirow{2}{*}{\multicolumn{4}{|c|}{$\begin{array}{c}* \mathrm{n}=42 ; * * \mathrm{n}=28 \\
\text { Tabel } 3\end{array}$}} \\
\hline & Tabel 3 & & hasil \\
\hline
\end{tabular}

hasil bahwa sebagian besar memiliki PMO yaitu sebanyak 28 orang $(66,7 \%)$ sedangkan yang tidak memiliki PMO sebanyak 14 orang $(33,3 \%)$.

\section{PEMBAHASAN}

Hasil penelitian yang sudah dilakukan di wilayah kerja Puskesmas I dan III Denpasar Utara dari 42 responden didapatkan jumlah penderita TB Paru yang memiliki kepatuhan tinggi yaitu sebanyak 29 orang $(69 \%), 9$ orang $(21,4 \%)$ memiliki tingkat kepatuhan sedang dan 4 orang $(9,5 \%)$ memiliki kepatuhan rendah. Data tersebut menunjukkan bahwa sebagian besar responden memiliki tingkat kepatuhan tinggi. Tingkat kepatuhan tinggi salah satunya dapat dipengaruhi oleh adanya motivasi. Motivasi dalam meningkatkan kesadaran dan keinginan berobat penderita sangat berpengaruh terhadap keberhasilan pengobatan TBC. Terkadang walaupun gejala penyakit mulai memberat, tetapi apabila penderitanya tidak merasa begitu sakit, penderita cenderung untuk tidak mencari pengobatan.

Hasil penelitian di atas sejalan dengan hasil penelitian yang dilakukan oleh Reza Dhiyantari, dkk (2015), berdasarkan jawaban responden yang telah diteliti didapatkan tingkat kepatuhan minum obat yang tinggi yaitu sebesar $86.67 \%$. Tingginya tingkat kepatuhan pengobatan pada responden dapat disebabkan oleh beberapa faktor pendukung, seperti obat-obatan dan layanan diberikan secara gratis, pusat pelayanan kesehatan yang mudah diakses oleh masyarakat serta adanya keinginan dari dalam diri untuk sembuh.

Hasil penelitian di atas juga didukung hasil penelitian yang dilakukan oleh Sari, Yuniar, \& Syaripuddin (2014), dikatakan bahwa 92 pasien yang menjadi responden dalam penelitian masih patuh dalam menjalani terapi antituberkulosis terbukti dengan tetap menjalani terapi antituberkulosis sampai selesai (selama 6 bulan) dan tidak terdapat obat sisa setiap bulan. Hal ini disebabkan karena adanya faktor yang tidak perlu rangsangan dari luar, yang berasal dari diri sendiri berupa motivasi, keyakinan, sikap dan kepribadian dari masing-masing responden. Sedangkan 
Ni Luh Kadek Fitria Dewi: Gambaran Kepatuhan Minum Obat pada Penderita Tuberkulosis

Paru

faktor yang perlu rangsangan dari luar berupa dukungan sosial dalam bentuk dukungan emosional dari anggota keluarga yang lain ataupun teman.

Dari hasil wawancara dengan penderita TB Paru, didapatkan hasil jumlah penderita yang memiliki PMO di rumah yaitu sebanyak 28 orang $(66,7 \%)$ sedangkan yang tidak memiliki PMO yaitu sebanyak 14 orang $(33,3 \%)$. PMO yang mengetahui semua jenis obat yang penderita TB Paru minum setiap hari hanya 2 orang $(7,1 \%)$, PMO mengatakan bahwa mereka sudah diberikan penjelasan tentang obat beserta fungsinya oleh petugas kesehatan saat kunjungan rumah. Sebagian besar PMO tidak mengetahui jenis obat penderita $(92,9 \%)$ hal ini disebabkan karena saat petugas kesehatan melakukan kunjungan rumah PMO sedang tidak ada di rumah dan ada beberapa PMO yang sedang bekerja. PMO yang selalu mengingatkan penderita TB Paru untuk minum obat mencapai $100 \%$. PMO yang mengingatkan untuk memeriksakan dahak ulang yaitu sebanyak 21 orang $(75 \%)$ sedangkan yang tidak selalu mengingatkan sebanyak $25 \%$ hal ini disebabkan karena PMO tidak mengetahui bahwa penderita harus memeriksakan dahak ulang. Sebagian besar PMO $(82,1 \%)$ sudah rutin mengajak penderita TB Paru ke pelayanan kesehatan.

Menurut Kemenkes RI (2014) untuk menjamin keteraturan pengobatan maka diperlukan adanya Pengawasan Menelan Obat (PMO). PMO adalah seseorang yang ditunjuk dan dipercaya untuk mengawasi dan memantau penderita TB dalam meminum obatnya secara teratur dan tuntas. Hasil wawancara di atas sejalan dengan hasil penelitian yang dilakukan oleh Reza Dhiyantari, dkk (2015), berdasarkan kepemilikan Pengawas Minum Obat (PMO), dari hasil penelitian ini didapatkan bahwa $94,4 \%$ responden memiliki pengawas minum obat. Tujuh belas orang responden yang memiliki PMO menyatakan bahwa PMO selalu mengingatkan untuk minum obat, selalu mengingatkan untuk mengambil obat dan mengecek dahak tepat waktu, serta menegur responden apabila lupa minum obat.

\section{KESIMPULAN}

Implikasi

Pada penelitian ini sebagian besar responden memiliki kepatuhan dalam pengobatan pada kategori tinggi. Penderita TB Paru diharapkan dapat lebih patuh terhadap program pengobatan yang sudah ditetapkan oleh petugas kesehatan, karena penyakit Tuberkulosis dapat sembuh secara total jika penderita patuh minum obat secara tuntas. Peran PMO perlu dimaksimalkan untuk mendukung kepatuhan minum obat.

\section{Keterbatasan}

Peneliti menyadari terdapat kekurangan dalam penelitian ini, dimana upaya meningkatkan kepatuhan perlu dilakukan. Lebih lanjut dapat dikembangkan model intervensi keperawatan sebagai bentuk langkah promotif dalam meningkatkan kepatuhan pengobatan TB Paru serta mencegah terjadinya resistensi terhadap obat.

\section{DAFTAR PUSTAKA}

Dinkes Prov. Bali. (2015). Profil Kesehatan Dinas Kesehatan Provinsi Bali.

Global TB Report (WHO). (2014). 19 Th Edition Global, WHO Press.

Hidayat, A.A. (2014). Metode Penelitian Keperawatan dan Teknik Analisis Data. Jakarta: Salemba Medika.

Info DATIN Kementerian Kesehatan RI. (2016). Tuberkulosis : Temukan Obati Sampai Sembuh. A

Kementerian PPN/Bappenas. (2017). Tujuan Pembangunan Berkelanjutan diakses pada tanggal 12 Februari 2017.

Morisky, D. E., Ang, A., Krousel-Wood, M., \& Ward, H. J. (2008). Predictive validity of a medication adherence measure in an outpatient setting. Journal of clinical hypertension (Greenwich, Conn.), 10 (5), 348-354.

Netty,E. (2013). Hubungan Peran Keluarga dengan Kepatuhan Minum Obat Pada Pasien Tuberkulosis di Puskesmas Kecamatan Jagakarsa. Health Quality, 4(2),82.

Nursalam. (2011). Konsep dan Penerapan Metodologi Penelitian Ilmu 
Ni Luh Kadek Fitria Dewi: Gambaran Kepatuhan Minum Obat pada Penderita Tuberkulosis Paru

Keperawatan, Jakarta: Salemba Medika.

Pameswari, P., Halim, A., \& Yustika, L. (2016). Tingkat Kepatuhan Penggunaan Obat pada Pasien Tuberkulosis di Rumah Sakit Mayjen H. A Thalib Kabupaten Kerinci.. JSFK (Jurnal Sains Farmasi \& Klinis), 2(2), 116-121.

Reza Dhiyantari, N., First Trasia, R., Dewi Indriyani, K., \& Aryani, P. (2015). Gambaran Kepatuhan Minum Obat Pada Penderita Tuberkulosis Paru Di Wilayah Kerja Puskesmas Bebandem, Karangasem. E-Jurnal Medika Udayana, 3(10) .

Sari, I., Yuniar, Y., \& Syaripuddin, M. (2014). Studi Monitoring Efek Samping Obat Antituberkulosis FDC Kategori 1 Di Provinsi Banten Dan Provinsi Jawa Barat. Media Penelitian Dan Pengembangan Kesehatan, 24(1), 28-35.

Tabrani, R. 2010. Ilmu Penyakit Paru. Jakarta: Trans Info Media.

World Health Organization. (2013a). Definition and Diagnosis of Pulmonology Tuberculosit.

World Health Organization. (2015b). Global Tuberculosis Report. 